ORIGINAL ARTICLE

\title{
Precocious pubarche is associated with SGA, prematurity, weight gain, and obesity
}

\author{
K A Neville, J L Walker
}

Arch Dis Child 2005;90:258-261. doi: 10.1136/adc.2004.053959

See end of article for authors' affiliations

Correspondence to:

Dr K A Neville,

Department of

Endocrinology, Sydney

Children's Hospital, High

St, Randwick, NSW 2031,

Australia; nevillek@sesahs.

nsw.gov.au

Accepted

9 September 2004
Background: Perinatal stress is thought to underlie the Barker sequelae of low birth weight, of which precocious pubarche may be a manifestation.

Aims: To explore whether prematurity as well as smallness for gestational age (SGA) predisposes to precocious pubarche, and the potential role of excess weight gain during childhood.

Methods: Retrospective chart review of 89 children (79 girls) with precocious pubarche.

Results: Sixty five per cent were overweight/obese at diagnosis, compared with 19-24\% of Australian children. Thirty five per cent had a history of SGA and $24 \%$ of prematurity. Weight SDS increased from birth to diagnosis in $91 \%$ of children. The mean change in weight SDS from birth to diagnosis was greater in those who were SGA $(2.8,95 \% \mathrm{Cl} 2.2$ to 3.4$)$ versus AGA $(1.7,95 \% \mathrm{Cl} 1.3$ to 2.2$)$, with no difference in the incidence of overweight/obesity. The latter was lower among children born premature $(40 \%$ versus $72 \%$ term) but was associated with a mean increase in weight of 1.3 SDS during childhood. Nine out of ten girls and boys with precocious pubarche had at least one of the three risk factors studied.

Conclusions: Both prematurity and SGA were associated with precocious pubarche, as was overweight/ obesity, irrespective of size or gestation at birth. Excess weight gain in childhood may predispose to precocious pubarche in susceptible individuals.
$\mathrm{T}$ he development of precocious pubarche, the appearance of sexual hair in girls under the age of 8 years and boys under the age of 9 years, ${ }^{1}$ has been linked in girls with a past history of low birth weight. ${ }^{2}{ }^{3}$ Moreover, a proportion of girls with precocious pubarche have been shown to develop polycystic ovarian disease ${ }^{4}$ (PCOS) and hyperinsulinism, ${ }^{6}$ a predictor of later cardiovascular disease. ${ }^{7}$ Precocious pubarche therefore may form part of the spectrum of pathology associated with low birth weight, as originally elaborated in the Barker hypothesis. ${ }^{8}$ Studies based on this hypothesis have suggested that poor growth in utero or during the first year of life may be associated with permanent changes in the hormonal milieu that promote the development of hyperinsulinism, ${ }^{9}$ type 2 diabetes mellitus, ${ }^{10}$ central obesity, ${ }^{11}$ and ischaemic heart disease ${ }^{12} 13$ later in life. The underlying mechanisms proposed include activation of a stress response resulting in chronically increased secretion of CRH, ACTH, and cortisol in utero. ${ }^{13}{ }^{14}$ Similar chronic activation might be expected postnatally in premature infants who are at increased risk of respiratory distress, infection, and undernutrition.

Rapid weight gain in childhood has been shown to increase the risk of ischaemic heart disease conferred by small size at birth, ${ }^{15}$ and is postulated to be an important trigger for the development of subsequent metabolic abnormalities in those with a pre-existing susceptibility. Anecdotally, precocious pubarche has been thought to be more common in children who are overweight, and recent data in French children provide evidence for this. ${ }^{16}$ Rapid weight gain in childhood might also link small size at birth and the subsequent development of precocious pubarche.

To investigate the contribution of birth size, gestational age, and childhood weight gain to the development of precocious pubarche in Australian children, we conducted a retrospective study of children diagnosed with precocious pubarche in our clinic.

\section{PATIENTS AND METHODS}

A retrospective chart review was performed of all patients presenting between December 1988 and May 2001 who were coded in the database of the Endocrine Department of Sydney Children's Hospital as having precocious pubarche. Precocious pubarche was defined as the onset of sexual hair at less than 8 years for girls and 9 years for boys, ${ }^{1}$ with sufficient duration of follow up and clinical and/or laboratory data to exclude other pathology, including the development of true precocious puberty.

Eighty nine children (79 girls) were identified as having a diagnosis of precocious pubarche and included in the study. Potential adrenal pathology was excluded biochemically in 85/89 children with an adrenal hormone profile and/or ACTH stimulation test, with the diagnosis resting on clinical grounds in the remaining four. The median age of onset of precocious pubarche in girls was 6.7 years (range 2.7-8.0) and boys 8.0 years (range 5.4-8.6). Of the seven girls aged $<4$ years, all had adrenal pathology excluded on biochemical grounds, a median bone age (BA) advance of 0.8 years (range $0-2.3$ years) and a median follow up period of 4 years (range 3.3-6.0 years). Data obtained for analysis from the patients' files included height and weight at diagnosis, gestational age (available in 84/89), birth weight (81/84), birth length (58/ $81)$, and BA (84/89).

Birth weights were expressed as a standard deviation score (SDS) and percentile for GA using recent Australian standards. ${ }^{17}$ Where a birth length was also available, a Ponderal Index (PI; weight/length ${ }^{3}$ ) was calculated and was classified as either above or below the 10th centile for Australian neonates. ${ }^{18}$ Because the PI relates weight to

Abbreviations: AGA, appropriate for gestational age; BA, bone age; $\mathrm{BMI}$, body mass index; $\mathrm{BW}$, birth weight; $\mathrm{GA}$, gestational age; $\mathrm{PI}$, Ponderal Index; SDS, standard deviation score; SGA, small for gestational age 
height, it may be a better indicator of nutritional constraint in utero and intrauterine growth retardation than birth weight alone. ${ }^{19}$ Children were classified as small for gestational age (SGA) if the birth weight and/or Ponderal Index were less than the 10th centile for GA. Prematurity was defined as a GA less than 37 weeks.

Weight, height, and BMI (weight/height ${ }^{2}$ ) at diagnosis were expressed as SDS and centiles in accordance with published data. ${ }^{20}{ }^{21}$ The difference between the chronological age (CA) and BA at diagnosis was calculated. Using the BMI at diagnosis, children were defined as overweight or obese according to the recently developed and published Cole standards. ${ }^{22}$ These standards relate a child's age and sex adjusted BMI SDS to a BMI of $25 \mathrm{~kg} / \mathrm{m}^{2}$ (overweight) or $30 \mathrm{~kg} / \mathrm{m}^{2}$ (obese) at age 18 years and therefore allow comparison across populations and over time. Gain in weight during childhood was assessed by comparing the difference between birth weight SDS and diagnosis weight SDS.

All statistical analyses were performed using the Statistical Package for Social Sciences (SPSS Inc., Chicago, IL, version 11.0 for Windows). Anthropometric measures were expressed as either mean $(95 \% \mathrm{CI})$ or median [range] unless otherwise indicated. Means between groups were compared by independent $t$ tests. Categorical data were analysed using cross tabulation and the $\chi^{2}$ test. Pearson's correlation coefficient was used to describe the correlation between two continuous variables. Statistically significance was defined as a $p$ value less than 0.05 .

\section{RESULTS}

At initial presentation for precocious pubarche the group was tall with a mean height SDS of 0.8 (0.6 to 1.1$)$, consistent with the mean bone age advance over chronological age of 0.9 years $(0.7$ to 1.1$)$. The mean weight SDS was 1.7 ( 1.3 to 2.0 ; table 1). Thirty of the 89 children were overweight $(33.7 \%)$ and $28 / 89$ obese $(31.4 \%)$. Fifty eight $(65.1 \%)$ children were therefore overweight or obese (table 1) compared with the recently published rate of overweight/obesity in Australian children of 19-24\%, defined by the same standards. ${ }^{23}$
In the 81 children in whom a birth weight (BW) and GA were available, the mean BW SDS was $-0.4(-0.7$ to -0.2$)$ and was less than the 10th centile for GA in $17 / 81$ (21\%; table 1). A Ponderal Index could be calculated for 58/81 and was less than the 10th centile in 16/58 (28\%). Twenty eight of the 81 children (35\%) had a BW and/or PI less than the 10th centile and were defined as SGA (table 1).

Of 84/89 children for whom GA was available, 20 (24\%) were premature, significantly higher than the rate of prematurity in New South Wales of $6.7 \%{ }^{24}(\mathrm{p}<0.001$, one way $\left.\chi^{2}\right)$. There was no difference in the rate of SGA among those who were premature $(25 \%)$ compared with those born at term (38\%; $p=0.3$, table 1$)$. The incidence of overweight/ obesity was significantly lower in those who were premature $(40 \%)$ versus those born at term $(72 \% ; p=0.01$, table 1$)$, although still higher than the rate of overweight/obesity in the general Australian child population $(\mathrm{p}<0.001$, one way $\left.\chi^{2}\right)$.

The mean gain in weight $(\Delta \mathrm{Wt})$ SDS from birth to diagnosis was 2.0 ( 1.7 to 2.4 ), with $90 \%$ (80/89) experiencing an increase in weight SDS. When analysed according to size at birth, there was no difference in weight SDS, BMI SDS, or incidence of overweight/obesity comparing those who were originally SGA to those who were appropriate for gestational age (AGA) (table 1). However, as by definition the mean birth weight SDS of the SGA children was lower than that of the AGA children, their "gain in weight" during childhood was significantly greater, with a mean $\Delta \mathrm{Wt}$ SDS from birth to diagnosis of 2.8 (2.2 to 3.4 ) versus 1.7 ( 1.3 to 2.2 ) for the AGA group $(p=0.005$, table 1$)$. The mean gain in weight SDS from birth to diagnosis in the children who were premature was significantly less than for the term group (1.3 (0.7 to 1.9) versus 2.3 ( 1.9 to 2.7 ); $\mathrm{p}=0.02$, table 1 ).

Seventy eight of the $89(88 \%)$ children studied were overweight/obese and/or had a history of SGA and/or prematurity. Of the 31/89 children who were of normal weight at diagnosis, GA was recorded in 30 and birth weight $+/-$ length in $29 / 30$. Forty per cent (12/30) were premature and $41 \%$ (12/29) were SGA, with $67 \%$ (20/30) premature and/ or SGA. Their mean gain in weight SDS from birth to diagnosis was 0.8 (0.3 to 1.2$)$.

\begin{tabular}{|c|c|c|c|c|c|c|c|}
\hline & \multirow[b]{2}{*}{$\begin{array}{l}\text { Whole group } \\
\mathrm{n}=89\end{array}$} & \multicolumn{2}{|l|}{ Weight status } & \multicolumn{2}{|l|}{ Gestation } & \multicolumn{2}{|l|}{ Birth weight } \\
\hline & & $\begin{array}{l}\text { Overweight/ } \\
\text { obese } \\
n=58\end{array}$ & $\begin{array}{l}\text { Normal } \\
n=31\end{array}$ & $\begin{array}{l}\text { Premature } \\
(<37 / 40) \\
n=20\end{array}$ & $\begin{array}{l}\text { Term } \\
n=64\end{array}$ & $\begin{array}{l}\text { SGA } \\
n=28\end{array}$ & $\begin{array}{l}\text { AGA } \\
n=53\end{array}$ \\
\hline Ageł & $\begin{array}{l}6.9 \\
{[2.7-8.6]}\end{array}$ & $\begin{array}{l}6.7 \\
{[2.7-8.6]}\end{array}$ & $\begin{array}{l}7.1 \\
{[2.7-8.5]}\end{array}$ & $\begin{array}{l}7.6 \\
{[4.1-8.5]}\end{array}$ & $\begin{array}{l}6.7^{* *} \\
{[2.7-8.6]}\end{array}$ & $\begin{array}{l}6.5 \\
{[2.7-8.6]}\end{array}$ & $\begin{array}{l}7.0 \\
{[2.8-8.4]}\end{array}$ \\
\hline Weight SDS† & $\begin{array}{l}1.7 \\
\text { (1.3 to } 2.0 \text { ) }\end{array}$ & $\begin{array}{l}2.5 \\
(2.2 \text { to } 2.9)\end{array}$ & $\begin{array}{l}0.0 \\
(-0.3 \text { to } 0.3)\end{array}$ & $\begin{array}{l}0.6 \\
(-0.1 \text { to } 1.2)\end{array}$ & $\begin{array}{l}2.0 * * * \\
(1.6 \text { to } 2.4)\end{array}$ & $\begin{array}{l}1.4 \\
(0.7 \text { to } 2.1)\end{array}$ & $\begin{array}{l}1.8 \\
(1.4 \text { to } 2.3 \text { ) }\end{array}$ \\
\hline BMI SDS† & 2.4 (1.9 to 2.9 ) & $\begin{array}{l}3.7 \\
(3.2 \text { to } 4.2 \text { ) }\end{array}$ & $\begin{array}{l}0.1 \\
(-0.3 \text { to } 0.4)\end{array}$ & $\begin{array}{l}1.2 \\
(0.2 \text { to } 2.2)\end{array}$ & $\begin{array}{l}2.8^{* *} \\
(2.2 \text { to } 3.4)\end{array}$ & 2.2 & $\begin{array}{l}2.6 \\
(1.9 \text { to } 3.2)\end{array}$ \\
\hline$\%$ overweight/obese (n) & $\begin{array}{l}65 \% \\
(58)\end{array}$ & & & $\begin{array}{l}40 \% \\
\text { (8) }\end{array}$ & $\begin{array}{l}72 \% * * \\
(46)\end{array}$ & $\begin{array}{l}57 \% \\
(16)\end{array}$ & $\begin{array}{l}68 \% \\
(36)\end{array}$ \\
\hline Gestational ageł & $\begin{array}{l}39 \\
{[25-42]}\end{array}$ & $\begin{array}{l}40 \\
{[25-42]}\end{array}$ & $\begin{array}{l}38 \\
{[29-42]}\end{array}$ & $\begin{array}{l}34 \\
{[25-36]}\end{array}$ & $\begin{array}{l}40 \\
{[37-40]}\end{array}$ & $\begin{array}{l}39 \\
{[25-42]}\end{array}$ & $\begin{array}{l}39 \\
{[25-42]}\end{array}$ \\
\hline$\%$ premature $(\mathrm{n})$ & $\begin{array}{l}24 \% \\
(20)\end{array}$ & $\begin{array}{l}15 \% \\
(8)\end{array}$ & $\begin{array}{l}40 \% \text { ** } \\
(12)\end{array}$ & & & $\begin{array}{l}18 \% \\
(5)\end{array}$ & $\begin{array}{l}28 \% \\
(15)\end{array}$ \\
\hline Birth weight SDS† & $\begin{array}{l}-0.4 \\
(-0.7 \text { to }-0.2)\end{array}$ & $\begin{array}{l}-0.2 \\
(-0.5 \text { to } 0.1)\end{array}$ & $\begin{array}{l}-0.8^{*} \\
(-1.1 \text { to }-0.4)\end{array}$ & $\begin{array}{l}-0.7 \\
(-1.2 \text { to }-0.3)\end{array}$ & $\begin{array}{l}-0.3 \\
(-0.6 \text { to } 0.0)\end{array}$ & $\begin{array}{l}-1.4 \\
(-1.8 \text { to }-1.1)\end{array}$ & $\begin{array}{l}0.1 \\
(-0.1 \text { to } 0.3)\end{array}$ \\
\hline$\%$ SGA (n) & $\begin{array}{l}35 \% \\
(28)\end{array}$ & $\begin{array}{l}31 \% \\
(16)\end{array}$ & $\begin{array}{l}41 \% \\
(12)\end{array}$ & $\begin{array}{l}25 \% \\
(5)\end{array}$ & $\begin{array}{l}38 \% \\
(23 / 61)\end{array}$ & & \\
\hline Gain in weight SDS† & $\begin{array}{l}2.0 \\
\text { (1.7 to } 2.4 \text { ) }\end{array}$ & $\begin{array}{l}2.7 \\
(2.3 \text { to } 3.1)\end{array}$ & $\begin{array}{l}0.7^{* * *} \\
(0.3 \text { to } 1.1)\end{array}$ & $\begin{array}{l}1.3 \\
(0.7 \text { to } 1.9)\end{array}$ & $\begin{array}{l}2.3^{*} \\
(1.9 \text { to } 2.7)\end{array}$ & $\begin{array}{l}2.8 \\
(2.2 \text { to } 3.4)\end{array}$ & $\begin{array}{l}1.7^{* \star} \\
(1.3 \text { to } 2.2)\end{array}$ \\
\hline $\begin{array}{l}\% \text { normal weight+ } \\
\text { Term + AGA (n) }\end{array}$ & $\begin{array}{l}12 \% \\
(11)\end{array}$ & NA & NA & NA & NA & NA & NA \\
\hline
\end{tabular}

$†$ Mean $(95 \% \mathrm{Cl})$, ‡median [range].

${ }^{*} p<0.05,{ }^{* *} p \leqslant 0.01,{ }^{* * *} p \leqslant 0.001$ 


\section{What is already known on this topic}

- Low birth weight increases the risk of a number of adult diseases, as originally postulated by the Barker hypothesis

- Precocious pubarche has been associated with low birth weight and hyperinsulinism, and therefore may form part of the spectrum of disease encompassed by the Barker hypothesis

Because of the small number of boys (consistent with published sex ratios ${ }^{1}$ ), statistical analysis was repeated after their exclusion with similar results (data not shown). When the 10 boys with precocious pubarche were analysed separately, the rate of overweight/obesity was $80 \%(8 / 10)$, $30 \%(3 / 10)$ had a past history of prematurity, and 33\% (3/9) were SGA. Only $1 / 10$ was not overweight/obese, premature, or SGA, as was the case when boys and girls were analysed together (table 1$)$.

\section{DISCUSSION}

Compared with published Australian standards, the children in our study with precocious pubarche had an increased incidence of overweight/obesity and an increased likelihood of having been SGA or premature, with 9/10 girls and boys presenting with at least one of these factors. The novel observation that prematurity is associated with an increased risk of precocious pubarche is consistent with the precocious pubarche being one of the sequelae of low birth weight and perinatal stress. The increase in weight SDS documented from birth to diagnosis in all groups (table 1) suggests that excess weight gain in childhood may provide the trigger for the development of precocious pubarche as is thought to be the case for other manifestations of the Barker hypothesis.

The prominence of overweight/obesity in the children studied is consistent with the postulated role for weight gain in the modulation of adrenal androgen secretion. ${ }^{25}$ The mean gain in weight during childhood of 2 SDS (table 1) in our study greatly exceeded that of 0.3 SDS shown in the ALSPAC longitudinal study of children followed from birth to 5 years. ${ }^{26}$ Sixty five per cent of the children presenting with precocious pubarche were overweight or obese, three times the rate of overweight/obesity in the Australian child population..$^{23}$ The frequency of obesity (31\%) we observed was similar to that recently reported in French children presenting with precocious pubarche. ${ }^{16}$ In children, the greatest increase in urinary DHEAS secretion occurs in the same year as the greatest increase in BMI, ${ }^{25}$ and in adults, experimentally induced fluctuations in weight have been shown to correlate directly with urinary adrenal androgen secretion. ${ }^{27}{ }^{28}$ Insulin has been implicated in the regulation of adrenal androgen secretion in in-vitro studies. ${ }^{29}$ The increased plasma insulin concentrations and decreased insulin sensitivity associated with increasing weight may underlie the link between adrenal androgen production and body mass.

A history of SGA and/or prematurity was also more frequent among the children presenting with precocious pubarche than expected in the general Australian population, ${ }^{17}{ }^{18} 24$ with $34 \%$ born SGA and 24\% premature. Moreover, two thirds of the 31 children who were of normal body weight at presentation had a history of SGA and/or prematurity. Previous studies have described an association between SGA and the later development of precocious pubarche, ${ }^{5616}$ but have not explored the potential effect of
What this study adds

- Prematurity as well as smallness for gestational age is more frequent than expected in children with precocious pubarche

- Overweight/obesity is more frequent in children with precocious pubarche than in the general population

- The association of precocious pubarche with SGA, prematurity, and with excess weight gain in childhood suggests that precocious pubarche may be a marker for hyperinsulinism

prematurity alone. Hormonal studies of premature infants born small or appropriate for gestational age have yielded conflicting results; ${ }^{30-32}$ however it is possible that the prenatal and/or postnatal stresses to which premature infants are subjected induce similar permanent reprogramming of the endocrine and metabolic pathways as is proposed for growth restricted infants. Of note, large population studies ${ }^{815} 3334$ examining the Barker hypothesis have linked low birth weight per se with later disease, without discriminating between children born prematurely or growth retarded.

Weight gain during childhood may be critical to the development of precocious pubarche in susceptible individuals. Epidemiological studies suggest that in children with low birth weight, relatively small increases in weight SDS and BMI during childhood magnify the risk of metabolic and endocrine sequelae. ${ }^{15}$ In twins discordant for birth size studied in late childhood, the lower birth weight twin had higher plasma concentrations of DHEAS than the higher birth weight twin if there had been catch-up in weight SDS of a degree similar to that observed in our study. ${ }^{35}$ Although our children with a past history of prematurity had a smaller increase in weight SDS during childhood (1.2 SDS) and a lower rate of overweight/obesity $(40 \%)$ than children born at term (table 1), both were higher than predicted by population studies. ${ }^{23} 26$ Even among the 20 premature and/or SGA children of normal weight at diagnosis, the median increase in weight SDS of $0.8 \mathrm{SD}$ was greater than that observed in the ALSPAC study.$^{26}$ Our data do not allow us to determine the independent contributions of low birth weight and increase in weight SDS during childhood to the development of precocious pubarche; however the effects of low birth weight and increased weight gain during childhood might be expected to be additive if the common underlying mechanism is hyperinsulinism. Decreased insulin sensitivity has been documented in children with a history of low birth weight ${ }^{36}$ and in girls of normal body weight with precocious pubarche, ${ }^{6}$ especially if there is a history of low birth weight. ${ }^{2}$ Moreover, a recent study ${ }^{37}$ showed that treatment with an insulin sensitiser of normal weight girls with a history of precocious pubarche and low birth weight improved body composition, decreased lipid abnormalities, and prevented progression to polycystic ovarian disease, suggesting that hyperinsulinism contributes to the pathogenesis of precocious pubarche in children of low birth weight.

A caveat to our conclusion that overweight/obesity and perinatal stress predispose to the development of precocious pubarche is the known ascertainment bias of hospital based studies. ${ }^{38}$ Children who are overweight, or have a history of other problems (for example, prematurity or SGA) may be more likely than other children to present to a hospital outpatient clinic, simply because they suffer from another condition and may have more encounters with medical practitioners leading to their referral. The relevance of the 
diagnosis of precocious pubarche, however, lies with whether it is a marker for something else because it is not a condition for which treatment is either required or available. The associations we observed are consistent with data suggesting that precocious pubarche may be a clinical marker for decreased insulin sensitivity, and this has implications for the counselling and follow up of affected children.

\section{Authors' affiliations}

K A Neville, J L Walker, Department of Endocrinology, Sydney Children's Hospital, Randwick, and School of Women's \& Children's Health, University of New South Wales, Sydney, Australia

Competing interests: none declared

\section{REFERENCES}

1 Ibanez L, Dimartino-Nardi J, Potau N, et al. Premature adrenarche-normal variant or forerunner of adult disease. Endo Rev 2000;21:671-96.

2 Ibanez L, Potau N, Francois I, et al. Precocious pubarche, hyperinsulinism and ovarian hyperandrogenism in girls: relation to reduced fetal growth. J Clin Endocrinol Metab 1998:83:3558-62.

3 Dimartino-Nardi J. Premature adrenarche: findings in prepubertal AfricanAmerican and Caribbean-Hispanic girls. Acta Pædiatr Suppl 1999; 433:72-7

4 Ibanez I, Potau N, deZegher F. Anovulation after precocious pubarche: early markers and time course on adolescence. J Clin Endocrinol Metab 1999;84:2691-5.

5 Ibanez L, Potau N, Virdis R, et al. Postpubertal outcomes in girls diagnosed of premature pubarche during childhood: increased frequency of functional ovarian hyperandrogenism. J Clin Endocrinol Metab 1993:76:1599-603.

6 Ibanez L, Potau N, Zampolli M, et al. Hyperinsulinism and decreased insulinlike growth factor binding protein-1 are common features in prepubertal and postpubertal girls with a history of premature pubarche. J Clin Endocrinol Metab 1997;82:2283-8.

7 Isomaa B, Almgren P, Tuomi T, et al. Cardiovascular morbidity and mortality associated with the metabolic syndrome. Diabetes Care 2001;24:683-9.

8 Barker DJP. Fetal origins of coronary heart disease. BMJ 1995;311:171-4.

9 Phillips DIW, Barker DJP, Hales CN, et al. Thinness at birth and insulin resistance in adult life. Diabetologia 1994;37:150-4

10 McKeigue PM, Leon DA, Berglund L, et al. Relationship of birthweight and ponderal index to non-insulin dependent diabetes and insulin response to glucose challenge in men aged $50-60$ years. Diabet Med 1994; 1 1 (suppl 17):S17.

11 Law CM, Barker DJ, Osmond C, et al. Early growth and abdominal fatness in adult life. J Epidemiol Community Health 1992;46:184-6.

12 Barker DJ, Winter PD, Osmond C, et al. Weight in infancy and death from ischaemic heart disease. Lancet 1989;2:577-80.

13 Barker DJ, Gluckman PD, Godfrey KM, et al. Fetal nutrition and cardiovascular disease in adult life. Lancet 1993:341:938-41.

14 Goland RS, Jozak S, Warren WB, et al. Elevated levels of umbilical cord plasma corticotropin-releasing hormone in growth-retarded fetuses. J Clin Endocrinol Metab 1993;77:1174-9.

15 Erikkson JG, Forsén T, Tuomilehto J, et al. Early growth and coronary heart disease in later life: longitudinal study. BMJ 2001;322:949-53.
16 Charkaluk ML, Trivin C, Brauner R. Premature pubarche as an indicator of how body weight influences the onset of adrenarche. Eur J Pediatr 2004; 163:89-93.

17 Beeby PJ, Bhutap T, Taylor LK. New South Wales population-based birthweight percentile charts. J Paediatr Child Health 1996;32:512-18.

18 Guaran RL, Wein P, Sheedy M, et al. Update of growth percentile for infants born in an Australian population. Aust N Z Obstet Gynaecol 1994;34:39-50.

19 Fay RA, Dey PL, Saadie CM, et al. Ponderal index: a better definition of the 'at risk' group with intrauterine growth problems than birth-weight for gestational age in term infants. Aust N Z J Obstet Gynaecol 1991;31:17-19.

20 Hamill PV, Drizd TA, Johnson CL, et al. Physical growth: National Center for Health Statistics percentiles. Am J Clin Nutr 1979;32:607-29.

21 Rolland-Cachera MF, Cole TJ, Sempe M, et al. Body mass index variations; centiles from birth to 87 years. Eur J Clin Nutr 1991;45:13-21.

22 Cole TJ, Bellizzi MC, Flegal KM, et al. Establishing a standard definition for childhood overweight and obesity worldwide: international survey. BMJ 2000;320:1240-3.

23 Booth ML, Wake M, Armstrong T, et al. The epidemiology of overweight and obesity among Australian children and adolescents, 1995-97. Aust NZJ Public Health $2001 ; 25: 162-9$.

24 NSW Department of Health. New South Wales Mothers and Babies 2000 NSW Public Health Bulletin Supplement 2001;12:S-3.

25 Remer T, Manz F. Role of nutritional status in the regulation of adrenarche. J Clin Endocrinol Metab 1999;84:3936-44.

26 Ong KKL, Ahmed ML, Emmett PM, et al. Association between postnatal catchup growth and obesity in childhood: prospective cohort study. $B M$ 2000;320:967-71.

27 Forbes GB, Brown MR, Welle SL, et al. Hormonal response to overfeeding. Am J Clin Nutr 1989;49:608-11

28 Hendrikx A, Heyns W, de Moor P. Influence of a low-calorie diet and fasting on the metabolism of dehydroepiandrosterone sulfate in adult obese subjects. J Clin Endocrinol 1968;28:1525-33.

29 Hines GA, Smith ER, Azziz R. Influence of insulin and testosterone in adrenocortical steroidogenesis in vitro; preliminary studies. Fertility and Sterility 2001;76:730-5.

30 Turnipseed MR, Bentley K, Reynolds JW. Serum dehydroepiandrosterone sulfate in premature infants and infants with intrauterine growth retardation. J Clin Endocrinol Metab 1976;43:1219-25.

31 Lee MM, Rajagopalan L, Berg GJ, et al. Serum adrenal steroid concentrations in premature infants. J Clin Endocrinol Metab 1989;69:1133-6.

32 Kari MA, Raivio KO, Stenman UH, et al. Serum cortisol, dehydroepiandrosterone sulfate, and steroid-binding globulins in preterm neonates: effect of gestational age and dexamethasone therapy. Pediatr Res 1996;40:319-24.

33 Stein $\mathrm{CE}$, Fall $\mathrm{CH}$, Kumaran $\mathrm{K}$, et al. Fetal growth and coronary heart disease in south India. Lancet 1996:348:1269-73.

34 Rich-Edwards JW, Stampfer MJ, Manson JE, et al. Birth weight and risk of cardiovascular disease in a cohort of women followed up since 1976. BMJ 1997:315:396-400.

35 Francois I, deZegher F. Adrenarche and fetal growth. Pediatr Res 1997;41:440-2.

36 Hofman PL, Cutfield WS, Robinson EM, et al. Insulin resistance in short children with intrauterine growth retardation. J Clin Endocrinol Metab 1997:82:402-6.

37 Ibanez L, Ferrer A, Ong K, et al. Insulin sensitization early after menarche prevents progression from precocious pubarche to polycystic ovary syndrome. $J$ Pediatr 2004; 144:23-9.

38 Berkson J. Limitations of the application of fourfold table analysis to hospital data. Biometrics Bull 1946;2:47-53. 